\title{
Reproductive Cycle of Blue- Striped Angelfish, Chaetodontoplus septentrionalis in Jeju Coastal Waters
}

\author{
Dae-Jong Kim ${ }^{1}$, Chi-Hoon Lee ${ }^{1,2}$, and ${ }^{\dagger}$ Young-Don Lee ${ }^{1}$ \\ ${ }^{1}$ Marine Science Institute, Jeju National University, Jeju 63333, Korea \\ ${ }^{2}$ CR Co., Ltd., Jeju 63333, Korea
}

Received: June 21, 2021

Revised: August 2, 2021

Accepted: August 29, 2021

${ }^{\dagger}$ Corresponding author Young-Don Lee

Marine Science Institute, Jeju National University, Jeju 63333, Korea.

Tel: +82-64-782-9730

Fax: +82-64-782-8281

E-mail:leemri@jejunu.ac.kr

Copyright $\odot 2021$ The Korean Society of Developmental Biology.

This is an Open Access article distributed under the terms of the Creative Commons Attribution Non-Commercial License (http://creativecommons.org/licenses/ by-nc/4.0/) which permits unrestricted non-commercial use, distribution, and reproduction in any medium, provided the original work is properly cited.

ORCID

Dae-Jong Kim

https://orcid.org/0000-0002-9234-4067

Chi-Hoon Lee

https://orcid.org/0000-0003-2165-9421

Young-Don Lee

https://orcid.org/0000-0003-2996-6952

Conflict of interests

The authors declare no potential conflict of interest.

Acknowledgements

This work was done while the author's his research year of Jeju National University in 2020.

Authors' contributions

Conceptualization: Lee YD.

Data curation: Kim DJ, Lee CH.

Formal analysis: Kim DJ, Lee CH, Lee YD.

Methodology: Lee YD.

Software: Kim DJ, Lee CH.

Validation: Kim DJ, Lee CH, Lee YD.

Investigation: Kim DJ, Lee CH.

Writing-original draft: Kim DJ, Lee CH,

LeeYD.

\section{Abstract}

Reproductive cycle of the blue-striped angelfish, Chaetodontoplus septentrionalis were histologically investigated. Fish were monthly collected in the coastal waters of Munseom, Seogwipo, Jeju-Island from February to December 2018. The gonadosomatic index (GSI) increased from May and maintained high values in August. The reproductive cycle of female fish can be classified by the characteristics observed during gonadal development as followed: growing stage (November to June), early mature stage (May to June), mature and spawning stage (June to September), and degenerative and recovery stage (September to December). In the male, testicular development period was similar to that of ovarian development period, but mature and spawning period was one month longer from June to October. Fecundity of mature female ranged from 4,601 to 22,840 and was correlated positively with total length and body weight. The histological analysis of gonadal development indicated that the $C$. septentrionalis was summer-spawning type and is considered a multiple spawner during spawning season.

Keywords: Reproductive cycle, Blue-striped angelfish, Chaetodontoplus septentrionalis, Summer-spawning

\section{INTRODUCTION}

In the waters of Jeju Island, new subtropical fish appear due to changes in water temperature, and unrecorded species are increasing every year (Choi et al., 2003). As a result of surveying the fish inhabiting the coastal waters of Jeju Island for two years from 2012 to 2013, subtropical fish accounted for $49.4 \%$ of all fish species, and blue-striped angelfish, Chaetodontoplus septentrionalis was the most dominant species (Ko et al., 2015). The blue-striped angelfish, C. septentrionalis is belonging to the family Pomacnthidae, order Perciformes, and is distributed in tropical waters of the western Pacific including Korea, Japan, Taiwan and China (Debelius et al., 2003). The body of an adult blue-striped angelfish has 8-10 narrow, long blue vertical stripes on a yellowish brown background, and the total length is about $22 \mathrm{~cm}$ (Kim et al., 2005).

The gonadal development of fish is controlled by both endogenous rhythms and exogenous environmental factor, and spawning events show species specificity (Donaldson \& Huter, 1983; Shimizu, 2003; Hermelink et al., 2011; Kanemaru et al., 2012). The reproductive cycle are known to 
Writing-review \& editing: Kim DJ, Lee CH, LeeYD.

Ethics approval

This article does not require IRB/IACUC approval because there are no human and animal participants. be regulated by changes of water temperature and photoperiod. The spawning patterns of fish are divided into spring-spawning, summer-spawning, and winter-spawning according to the seasonal change (Aida, 1991).

There are 1,500 species of global marine ornamental fish. The marine ornamental fish consumed in Korea are clownfish and sea horses, and most are imported from tropical Southeast Asian countries such as Indonesia and Polynesia. Most of the ornamental fish are freshwater fish, and although the supply is stable through the production of artificial seedlings, the price is lower than that of the marine ornamental fish. Due to the high value of the marine ornamental fish, many studies are being conducted for the production of artificial seeds (Allen et al., 1998; Anil et al., 1999).

The blue-striped angelfish, C. septentrionalis is a fish species of high ornamental value due to its colorful body color, and is priced at 200 USD pre individual in the marine ornamental fish market (Chen \& Tzeng, 2009). Previous studies on the blue-striped angelfish have been investigated about spawning pastern (Chen \& Tzeng, 2009) and spawning heavier and early life history (Leu et al., 2010). However, the characteristics of reproductive biology have not been studied yet. The present study investigated the reproductive cycle based on changes gonadosomatic index (GSI), gametogenesis, gonadal development and fecundity in order to characterize the reproductive biology of blue-striped angelfish, $C$. septentrionalis inhabiting the coastal waters of Jeju Island, Korea.

\section{MATERIALS AND METHODS}

The blue-striped angelfish, C. septentrionalis was sampled by scuba diving (directly hand collection) at a depth of 15 meters in the coastal waters of Munseom, Seogwipo of Jeju-Island, Korea. Fish were monthly collected from February to December 2018. During sample collection, the water temperature at the sampling site (depth $15 \mathrm{~m}$ ) was measured using HOBO U26001 data logger (Onset, Bourne, MA, USA). Data from the Jeju Meteorological Administration were used for the photoperiod. For histological analysis on the gonadal development, fish were anaesthetized with 2-phenoxyethanol (Sigma-Aldrich, St. Louis, Mo, USA) and then gonad were extracted. Dissected gonads were weighted to calculate GSI (gonad weight / body weigh $\times 100$ ). The dissected gonads were fixed for 24 hours in Bouin's solution and then embedded in paraffin. The paraffin-embedded tissues were sectioned at 5-6 $\mu \mathrm{m}$ and stained with Gill's hematoxylin and $0.5 \%$ eosin, and the specimens were examined under a light microscope (Olympus BX53, Japan). Fecundity (F) was measured by a number of isolated oocytes from partial ovary that were not spawned. After isolating oocytes with Gilson's solution, fecundity was calculated according to the following formula: $\mathrm{F}=\mathrm{W} / \omega \times \varepsilon$. W is gonad weight, $\omega$ is partial gonad weight, and $\varepsilon$ is weight ratio. Increase in fecundity with total length, body weight was calculated with a formula of $F$ $=\mathrm{a}(\mathrm{TL})^{\mathrm{b}}$ and $\mathrm{F}=\mathrm{a}(\mathrm{BW})^{\mathrm{b}}$, respectively.

\section{RESULTS}

\section{Morphological feature and structure of gonad}

The adult of blue-striped angelfish, C. septentrionalis is yellowish brown in abdomen, and the blue color becomes stronger as it goes toward the tail, and the tail fin is yellow. There are 7-12 narrow and long blue stripes from the head to the tail, and the stripes show a certain pattern, 
but all individuals show slightly different types of stripes. The stripes reflect light when observed underwater, making them look more colorful (Fig. 1A and B). The gonad of blue-striped angelfish was a paired organ suspended by a thin mesorchium from the dorsal side of the peritoneal cavity. During mature stage, the ovary and testis were light pink color pale red and milk-white, respectively (Fig. $1 \mathrm{C}$ and D). As a result of histological observation of gonad, the ovary was ectovarian sac type, and consisted of numerous ovarian lobules (Fig. 1E). The testis was lobule type, and consisted of numerous testicular lobules (Fig. 1F).

\section{Monthly change of gonadosomatic index (GSI) and hepatosomatic index (HSI)}

The GSI of female was $1.2 \pm 0.1$ between February $\left(11 \mathrm{~L}: 13 \mathrm{D}, 14.3^{\circ} \mathrm{C}\right)$ to April (13L:11D, $\left.19.9^{\circ} \mathrm{C}\right)$, thereafter began to increase to $2.4 \pm 0.4$ from June $\left(14.4: 9.6 \mathrm{D}, 19.9^{\circ} \mathrm{C}\right)$. The mean values of GSI reached the highest at 5.0 \pm 0.5 in August (13.9L: 10.1D, $26.4^{\circ} \mathrm{C}$ ). Then, GSI decreased from
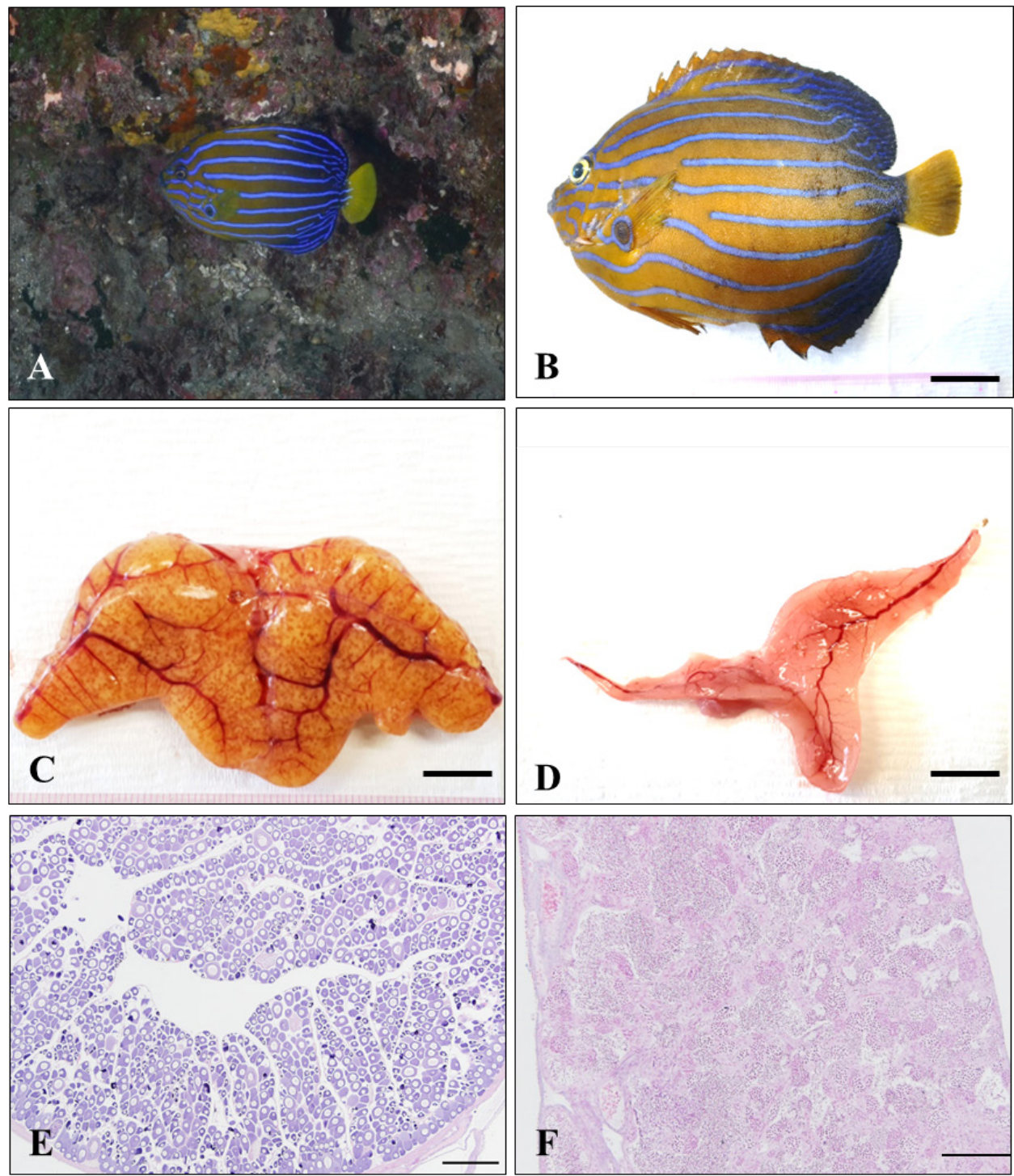

Fig. 1. Morphological characteristics of Chaetodontoplus septentrionalis. (A), (B), Picture of blue-striped angelfish $(B a r=2.0 \mathrm{~cm})$. (C) and $(D)$, External morphology of ovary $(C)$ and testis $(D)(B a r=1.0 \mathrm{~cm})$. $(E)$ and $(F)$, Photomicrograph of ovary $(E)$ and testis $(F)$. Hematoxylin and eosin stain (Bar $=200 \mu \mathrm{m})$ 
September, and was lower between October (11.1L: 13.9D, 20.0 ${ }^{\circ}$ ) to December (9.8L: 14.2D, $\left.16.5^{\circ} \mathrm{C}\right)$. The monthly change of male was similar to female but the highest values was observed on July. In male, the GSI values was lower between February to May and ranged $0.15 \pm 0.02$ to $0.28 \pm 0.09$. The GSI began to increase to $0.51 \pm 0.18$ from June, thereafter reached the highest at $0.87 \pm 0.28$ in July. Then, GSI decreased from August, and was lower between October to December (Fig. 2A and B). The HSI of female was low at $1.4 \pm 0.2$ from February to June. It increased rapidly to $7.3 \pm 1.3$ in July, showing one sample was relatively highest at 12.0. Afterwards, it decreased drastically and then stabilized between $2.0 \pm 0.4$ and $1.1 \pm 0.1$ from August until December. The males showed a relatively
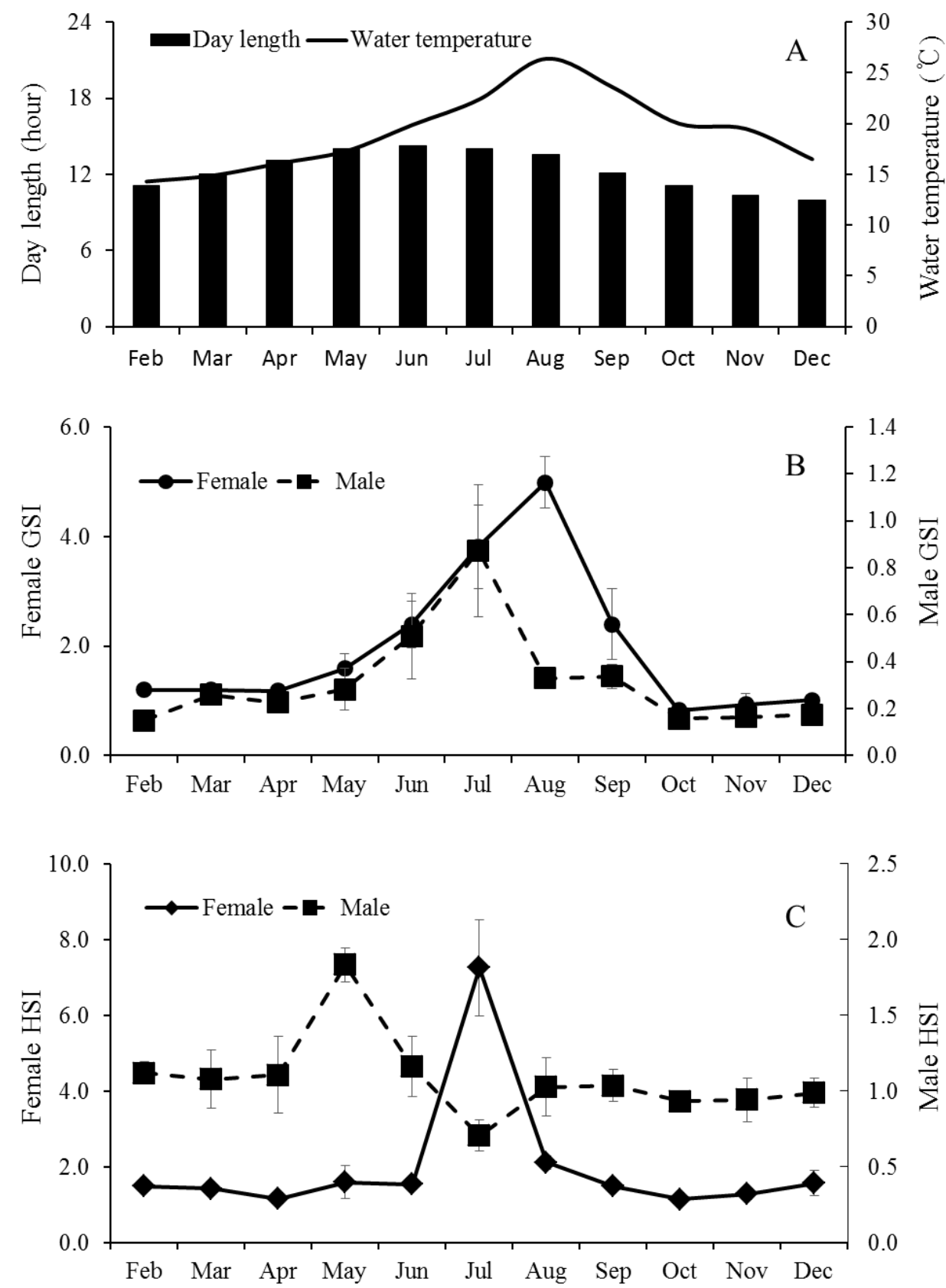

Fig. 2. Monthly changes of water temperature and day length (A), gonadosomatic index (GSI) and hepatosomatic index (HSI) of Chaetodontoplus septentrionalis from February to December 2018. 
higher HSI in May (Fig. 2C). The HSI, however, decreased drastically afterwards showing the lowest value $(0.7 \pm 0.1)$ in July. As the histological observation of the liver of female C. septentrionalis in July, the glycogen and lipid droplets were observed in liver tissue (Fig. 3).

\section{Oogenesis}

In the growing ovary, chromatin nucleolus oocytes with $10-20 \mu \mathrm{m}$ in diameter and perinucleolus oocytes with $20-120 \mu \mathrm{m}$ in diameter were observed in the ovarian lobule (Fig. 4A). As the oocytes grows, zona radiata was formed, and oil droplets and yolk granules accumulated in the cytoplasm (Fig. 4B). In the maturing stage, yolk granules and oil droplets became more eosin-
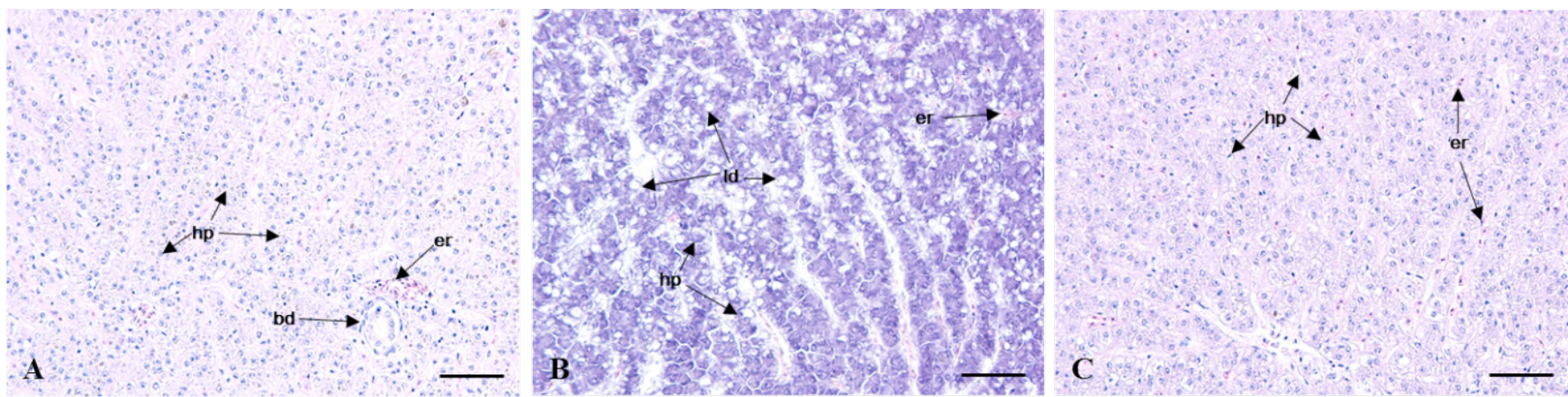

Fig. 3. Histological feature of hepatic tissue in Chaetodontoplus septentrionalis. (A) April before spawning season. (B) July during spawning season. (C) October after spawning season. bd, bile duct; er, erythrocyte; hp, hepatocyte; Id, lipid droplets. Hematoxylin and eosin stain $(B a r=40 \mu m)$.
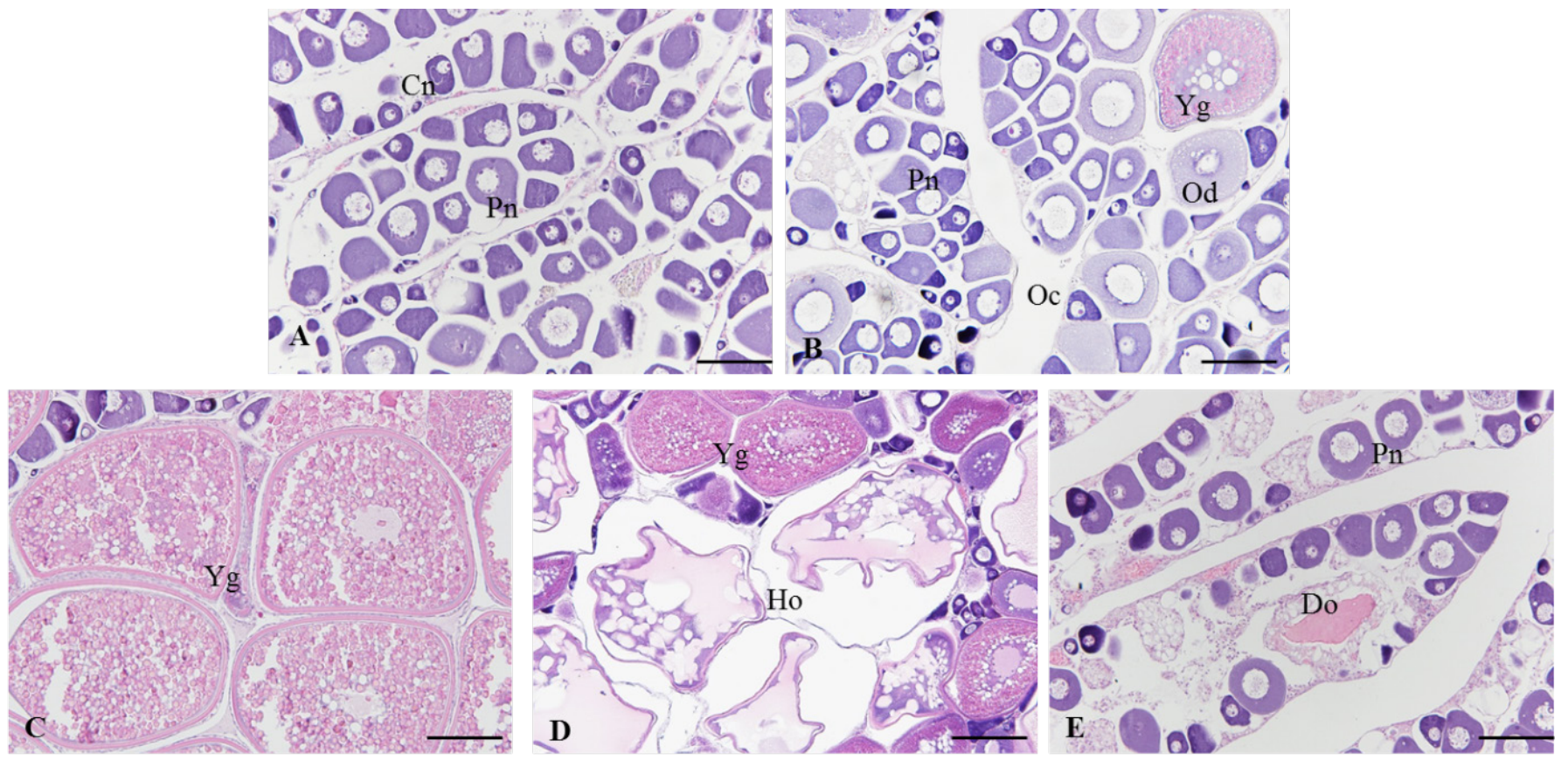

Fig. 4. Photomicrographs of ovarian developmental stage in Chaetodontoplus septentrionalis. (A) Growing stage. (B) Early mature stage. (C), (D) Mature and spawning stage. (E) Degenerative and recovery stage. Hematoxylin and eosin stain. Scale bars indicate $100 \mu \mathrm{m}(\mathrm{A}),(\mathrm{B})$ and $(\mathrm{E})$ and 200 $\mu \mathrm{m}(\mathrm{C}),(\mathrm{D})$. Cn, chromatin nucleolus oocytes; Do, degenerating oocyte; Ho, hydrating oocyte; Oc, ovarian cavity; Od, oil droplet; Pn, peri-nucleulus; Yg, yolk globule. 
basophilic and the oocytes increased and the diameter ranged from 250 to $450 \mu \mathrm{m}$ (Fig. 4C and D). After spawning, postovulatory follicles were observed and undischarged mature oocytes mostly degenerated. During the degenerating and recovery stage, the ovarian membrane layer thinned again and the ovary vesicles rearranged. Also, many basophilic chromatin nucleolus oocytes and perinucleolus oocytes were distributed around epithelium of ovarian lobules (Fig. 4E).

\section{Spermatogenesis}

In the growing stage, the spermatogonia were multiplied along the epithelium of testicular lobules (Fig. 5A). Thereafter, the testicular lobule enlarges and numerous spermatocytes and spermatids develop from the epithelium of testicular lobules (Fig. 5B). During the mature and spawning stage, testicular lobules more expanded and filled with sperm. Some of the matured males released sperm during this stage (Fig. 5C). In the degenerating and recovery stage, a few spermatozoa still remained and the undischarged spermatozoa degenerated or were absorbed. The spermatogonia were distributed on the epithelium of testicular lobules (Fig. 5D).

\section{Reproductive cycle}

Based on gametogenesis and gonadal development, the reproductive cycle of blue-striped angelfish, $C$. septentrionalis could be grouped into successive stage, namely growth, early mature, mature and spawning, and degenerative and recovery stage (Fig. 6).

\section{1) Growth stage}

In the ovary, growth stage consisted of chromatin nucleolus with 10-20 $\mu \mathrm{m}$ in diameter and perinucleolus oocytes with $20-120 \mu \mathrm{m}$ in diameter. They appeared from November to April. In the
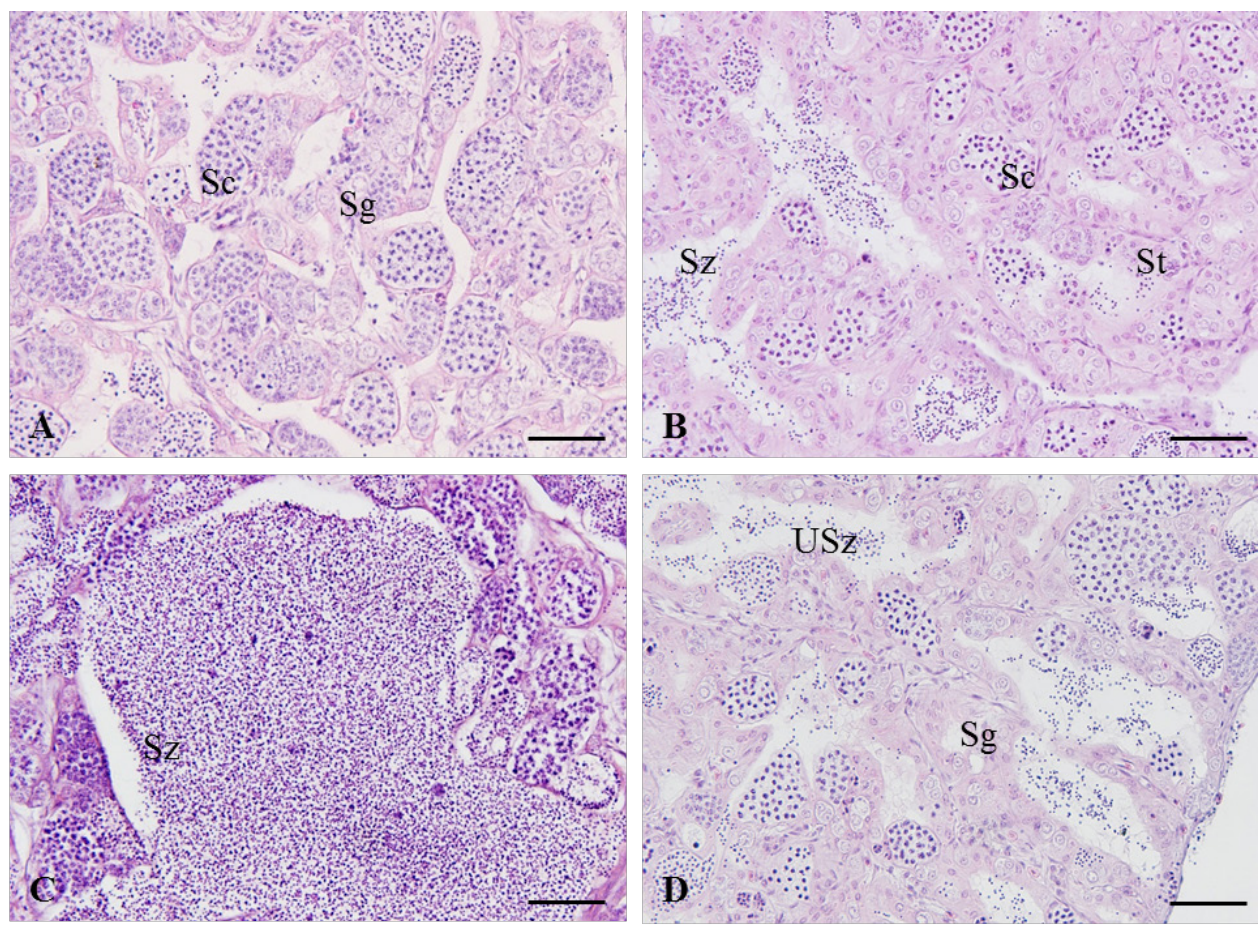

Fig. 5. Photomicrographs of testicular developmental stage in Chaetodontoplus septentrionalis. (A) Growing stage. (B) Early mature stage. (C) Mature and spawning stage. (D) Degenerative and recovery stage. Hematoxylin and eosin stain $(B a r=40 \mu \mathrm{m})$. Sc, spermatocytes; Sg, spermatogonia; St, spermatid; $\mathrm{Sz}$, spermatozoa; USz, undischarged spermatozoa. 


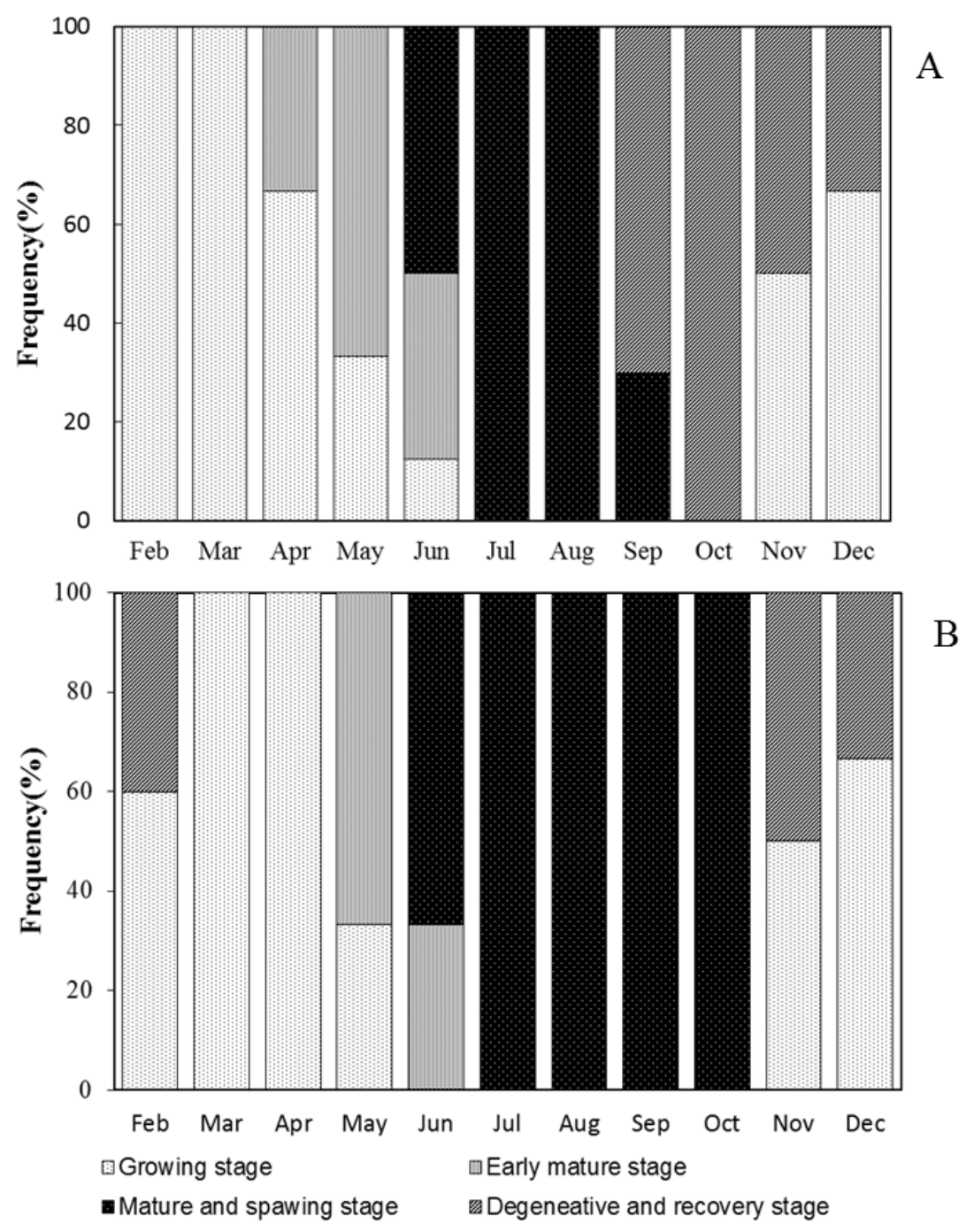

Fig. 6. Frequency of gonadal developmental phase in Chaetodontoplus septentrionalis from February to December 2018. (A) Female, (B) male.

testis, a few spermatogonia and numerous spermatocytes were observed testicular lobule. This stage appeared from November to April.

\section{2) Early mature stage}

The ovary was mixed of perinucleolus oocytes and oil-droplet oocytes with $120-250 \mu \mathrm{m}$ in diameter. Also, vitellogenic coocytes that began to accumulate yolk granules in their cytoplasm were observed. The yolk vesicle oocytes were $300 \mu \mathrm{m}$ in diameter. In the testis, the number of spermatogona decreased, and numerous spermatocyte and spermatid occupied the majority of the testicular lobule. They appeared form May to June.

\section{3) Mature and spawning stage}

As the ovary matured, the gonadsomatic index increased rapidly. The mature ovary had a few young oocytes, but yolk vesicle oocytes with $250-450 \mu \mathrm{m}$ in diameter occupied the majority of the ovarian follicles. Also, the mature oocyte with numerous yolk granules homogeneously distributed 
in the cytoplasm and postovulatory follicles were observed. They appeared form June to September. In the testis, numerous sperms were observed within testicular lobule, and this stage appeared form June to October.

\section{4) Degenerative and recovery stage}

From this stage, GSI decreased rapidly. In the ovary, undischarged mature oocytes mostly degenerated and young oocytes began to grow in the ovarian follicle. They appeared from September to December. In the degenerative and recovery stage testis, undischarged sperm in the testicular lobule mostly degenerated and spermatogonia were observed along the germinal epithelium. This stage appeared from November to February.

\section{Fecundity}

The fecundity of blue-striped angelfish, $C$. septentrionalis ranged from 4,601 (fish TL=15.1 $\mathrm{cm}$, weight=103.27 g) to 22,840 (fish $\mathrm{TL}=19.2 \mathrm{~cm}$, weight=175.14 g). The regression equation of fecundity $(\mathrm{F})$ on total length and body weight was established on an arithmetic scale for bluestriped angelfish, C. septentrionalis: $\mathrm{F}=63.16 \mathrm{TL}^{0.3026}\left(\mathrm{R}^{2}=0.5464\right)$ and $\mathrm{F}=791.81 \mathrm{BW}^{0.0193}\left(\mathrm{R}^{2}=0.7577\right)$. The regression equation showed a positive linear relationship between total length and fecundity (Fig. 7A), and body weight and fecundity (Fig. 7B).
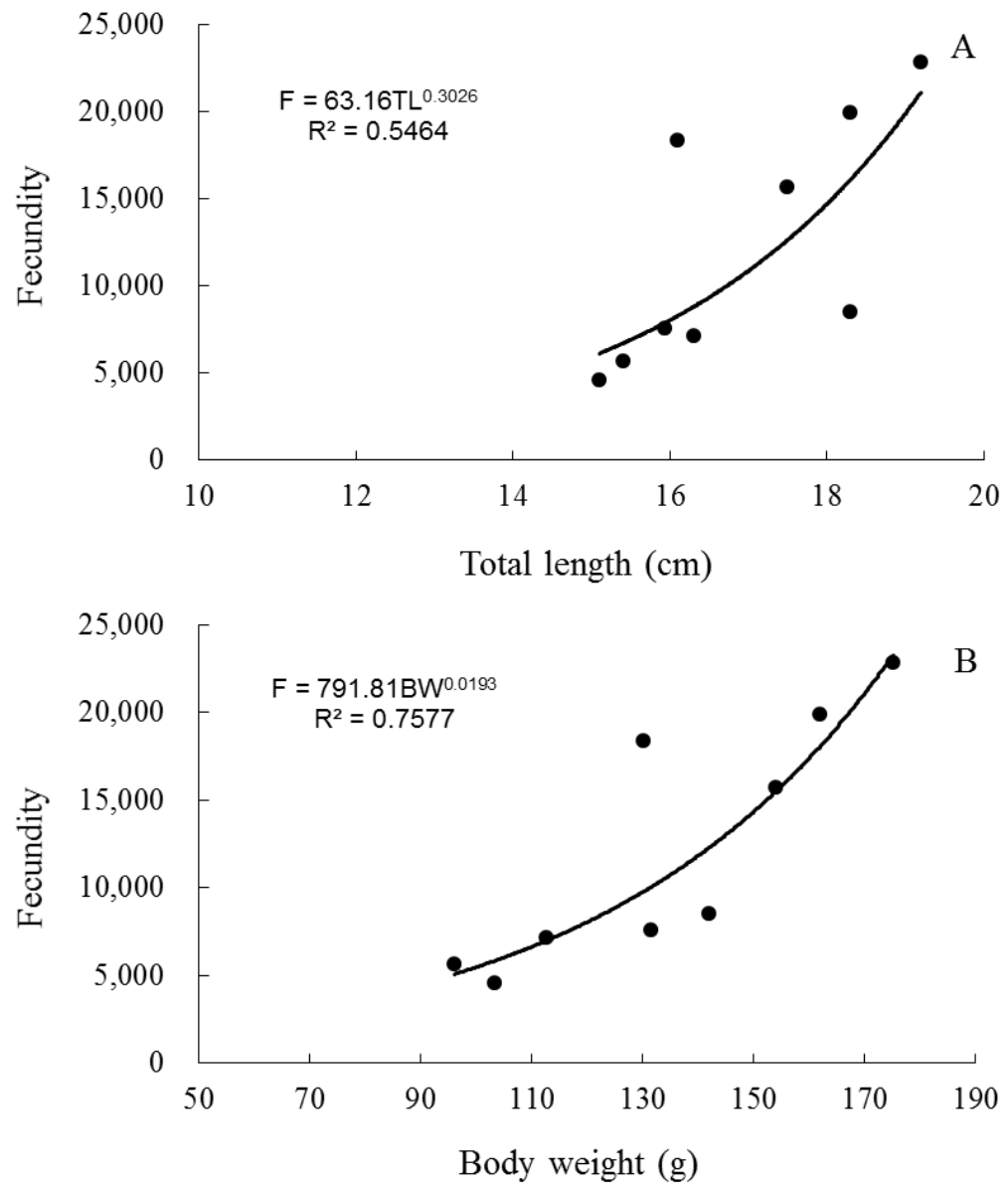

Fig. 7. Relationship between total length and fecundity (A), body weight and fecundity (B) of Chaetodontoplus septentrionalis. 


\section{DISCUSSION}

The reproductive cycle and spawning season depends on periodical changes of water temperature and photoperiod. The spawning patterns of fish are divided into spring-spawning, summer-spawning, autumn-spawning, and winter-spawning according to the seasonal change (Aida, 1991). In fish inhabiting coastal waters of Jeju Island, black rockfish, Sebastes scblegeli is the springspawning type (Park et al., 2001), and damselfish, Chromis notatus (Lee \& Lee, 1987), multicolorfin rainbowfish, Halichoeres poecilopterus (Lee et al., 1991), cocktail wrasse, Pteragogus flagellifera (Lee et al., 1992), filefish, Stephanolepis cirrbifer (Lee et al., 2000), and grass puffer, Takifugu niphobles (Kim, 2016) is summer-spawning type. The autumn-spawning fish is bambooleaf wrasse, Pseudolabrus japonicus (Lee et al., 1992), horsehead tilefish, Branchiostegus japonicas (Choi et al., 2004), and winter-spawning fish is marbled rockfish, Sebastiscus marmoratus (Bae et al., 1998) and grey mullet, Mugil cephalus (Kim et al., 2004). In the Taiwan, C. septentrionalis might spawn in a single season annually, and its reproductive activity might peak in summer (Chen \& Tzeng, 2009). In this study, the gonadal development of C. septentrionalis coincided with rising water temperatures, and spawning occurred from July to September, when the temperature was high. These results suggest that the gonadal development and spawning of this species are closely correlated with water temperature, and spawning pattern was summer-spawning type.

In fish, the vitellogenin (VTG) are synthesized and secreted by the liver under the stimulation of ovarian estrogen (Sullivan \& Yilmaz, 2018). It plays a very important role in the formation of yolk protein in the gonad (Okumura et al., 2001). In this study, the HSI of C. septentrionalis did not indicate any significant relation to the GSI changes in males. However, the changes in the HSI during the spawning season are related to the GSI changes in female. The female GSI reached it's the highest value in August, but the HSI reached it's the highest value in July. These results suggest that the HSI increases during spawning season as VTG and nutrients synthesize actively in the liver, VTG is transferred to the ovaries from July to September then the HSI decreases.

In fish, the fecundity that can be used to determine the reproductive potential varies from species to species. The fecundity of gobies varied depending on the species, and produced 100 eggs to 500,000 eggs (Ha \& Kinzie, 1996; Jin et al., 2006). In the spotted sea bass, Lateolabrax maculatus, fecundity was about 170,000 eggs as body weight and total length increase (Kim et al., 2001), rabbitfish, Siganus canaliculatus was produced approximately 140,000 eggs (Hwang et al., 2004). Fecundity was positively correlated with fish size. Species of this type include damselfish, Chromis notatus (Lee \& Lee, 1987), silver pomfret, Pampus argenteus (Chung et al., 2008), stone flounder, Kareius bicoloratus (Jun et al., 2009), tongue sole, Cynoglossus semilaevis (Kang et al., 2012) and chameleon goby, Tridentiger trigonocephalus (Hwang et al., 2013). Independent of total length and body weight gain, grunt, Hapalogenys nitens produced eggs (Kang et al., 2015). In this study, fecundity of $C$. septentrionalis was ranged from 4,601 to 22,840 eggs. Also, as the total length and body weight increased, the fecundity increased.

In conclusion, the C. septentrionalis was summer-spawning type and the peak spawning occurs in June and September. The histological observation of gonadal development indicates that the C. septentrionalis is considered a multiple spawner during spawning season and show an increased fecundity when the body length and body weight increase.

\section{REFERENCES}

Aida K (1991) Environmental regulation of reproductive rhythms in teleosts. Bull Inst Zool Acade 
Sin Monogr 16:173-188.

Allen GR, Steen R, Allen M (1998) A Guide to Angelfishes and Butterflyfishes. Odyssey, New York, NY, pp 1-250.

Anil MK, Kakati VS, Ganga U, Zacharia S (1999) Larval rearing of seahorse Hippocampus kuda under laboratory conditions. Mar Fish Inf Ser 162:23-25.

Bae HC, Chung SC, Lee JJ, Lee YD (1998) Annual reproductive cycle and embryonic development within the maternal body of the marbled rockfish, Sebastiscus marmoratus from the Cheju Island.J Korean Fish Soc 31:489-499.

Chen KY, Tzeng WN (2009) Reproductive mode of the blue-striped angelfish Chaetodontoplus septentrionalis in northeastern Taiwan. Zool Stud 48:468-476.

Choi JK, Kim HJ, Park CB, Lee CH, Song YB, Lee KJ, Yeo IK, Lee JU, Chang DS, Ha DS, Lee YD (2004) Annual reproductive cycle and sexual characteristics of Horsehead Branchiostegus japonicus. Korean J Ichthyol 16:282-294.

Choi Y, Oh JK, Ra HK (2003) Fish fauna of the southern coastal waters in Jeju-do, Korea. Korean J Ichthyol 15:120-126.

Chung EY, Bae JS, Kang HW, Lee HB, Lee KY (2008) Reproductive ecology of the silver pomfret Pampus argenteus on the west coast of Korea. Dev Reprod 12:169-181.

Debelius H,Tanaka H, Kuiter RH (2003) Angelfishes: A Comprehensive Guide to Pomacanthidae. TMC, Chorleywood, UK.

Donaldson EM, Huter GA (1983) 7 Induced final maturation, ovulation and spermiation in cultured fishes. In: Hoar WS, Randall DJ, Donaldson EM (eds), Reproduction: Endocrine tissues and Hormones, Academic Press, Orlando, FL, pp 351-403.

Ha PY, Kinzie RA III (1996) Reproductive biology of Awaous guamensis, an amphidromous Hawaiian goby. Environ Biol Fishes 45:383-396.

Hermelink B, Wuertz S, Trubiroha A, Rennert B, Kloas W, Schulz C (2011) Influence of temperature on puberty and maturation of pikeperch, Sander lucioperca. Gen Comp Endocrionol 172:282-292.

Hwang HK, Park CB, Kang YJ, Lee JH, Rho S, Lee YD (2004) Gonadal development and reproductive cycle of the rabbitfish (Siganus canaliculatus).J Korean Fish Soc 37:393-399.

Hwang IJ, Baek HJ (2013) Reproductive cycle of chameleon goby, Tridentiger trigonocephalus in the southern coastal waters of Korea. Dev Reprod 17:353-361.

Jun JC, Kang HW, Kim BG, Choi KH, Jo KC (2009) Fecundity and hatch rate of natural stone flounder Kareius bicoloratus from the west coast of Korea. Korean J Ichthyol 21:239-246.

Jin YS, Park CB, Kim HJ, Lee CH, Song YB, Kim BH, Lee YD (2006) Reproductive cycle of dusky tripletooth Goby Tridentiger obscurus in Jeju Island, Korea. Korean J Ichthyol 18:184192.

Kanemaru T, Nakamura M, Murata R, Kuroki K, Horie H, Uchida K, Senthilkumaran B, Kagawa $\mathrm{H}$ (2012) Induction of sexual maturation of the female honeycomb grouper, Epinephelus merra, in the non-breeding season by modulating environmental factors with $\mathrm{GnRH}$ analogue implantation. Aquaculture 358:85-91.

Kang HW, Lim HG, Kang DY, Han HS, Do YH, Park JS (2012) Maturation and spawning of the female tongue sole, Cynoglossus semilaevis in the west coast in Korea. Dev Reprod 2:87-93.

Kang HW, Cho JK, Son MH, Hong CG, Park JY, Kim SH (2015) Gonadal maturation, fecundity and reproductive potential of the indoor cultured grunt, Hapalogenys nitens.J Fish Mar Sci Edu 27:990-997.

Kim BH (2016) Role of melatonin on the regulation of reproductive system in the grass puffer, Takifugu niphobles. Ph.D. Dissertation, Jeju National University, Jeju, Korea. 
Kim IS, Choi Y, Lee CL, Lee YJ, Kim BJ, Kim JH (2005) Illustrated Book of Korean Fishes. Kyohaksa, Seoul, Korea, p 352.

Kim SJ, Lee YD, Yeo IK, Baek HJ, Kim HB, Nagae M, Soyano K, Hara A (2004) Reproductive cycle of the female grey mullet, Mugil cephalus, on the coast of Jeju Island, Korea. J Environ Toxicol 19:73-80.

Kim SY, Bang IC, Rho YG, Kim JH (2001) Studies on sexual maturation of spotted sea bass, Lateolabrax maculatus.J Korean Fish Soc 34:526-535.

Ko JC, Kim BY, Kim MJ, Park SE, Kim JB, Cho HK (2015) A seasonal characteristic of marine environment and fish assemblage in the coastal waters Jeju Island, Korea from 2012 to 2013. J Fish Mar Sci Educ 27:319-344.

Lee YD, Lee TY (1987) Studies on the reproductive cycle of damselfish, Chromis notatus (Temminck et Schlegel). Bull Korean Fish Soc 20:509-519.

Lee YD, Rho HK, Lee TY (1991) Reproductive ecology of the wrasse, Halichoeres poecilopterus (Temmink et Schlegel). Bull Mar Res Inst Cheju Nat Univ 15:93-102.

Lee YD, An CM, Lee JJ, Lee TY (1992). Reproductive cycle and sex reversal of Pseudolabrus japonicas (Houttuyn). Bull Mar Res Inst Cheju Natl Univ 16:55-66.

Lee YD, Go YB, Chung SC (1992). Reproductive cycle and sex reversal of the ock-tail wrasse, Pteragogus flagellifer. Bull Mar Res Inst Cheju Natl Univ 16:43-53.

Lee SJ, Go YB, Lee YD (2000) Annual reproductive cycle of the file fish, Stephanolepis cirrbifer, on the southern coast of Cheju Island. Korean J Ichthyol 12:62-70.

Leu MY, Meng PJ, Huang CS, Tew KS, Kuo J, Liou CH (2010) Spawning behaviour, early development and first feeding of the bluestriped angelfish [Chaetodontoplus septentrionalis (Temminck \& Schlegel, 1844)] in captivity. Aquacult Res 41:39-52.

Okumura H, Saeki F, Matsubara H, Adachi S, Yamauchi K (2001) Changes in serum vitellogenin levels and immunohistochemical localization of vitellogenin in hepatic cells during ovarian development in the Japanese eel. Fish Sci 67:880-887.

Park ME, Rho S, Byun SC, Lee CH, Baek HJ, Lee YD, Kim HB (2001) Regulation of copulation and parturition in black rockfish, Sebastes scblegeli by photoperiod and temperature. J Aquacult 14:173-180.

Shimizu A (2003) Effect of photoperiod and temperature on gonadal activity and plasma steroid levels in a reared strain of the mummichog (Fundulus heteroclitus) during different phases of its annual reproductive cycle. Gen Comp Endocrinol 131:310-324.

Sullivan CV, Yilmaz O (2018) Vitellogenesis and Yolk Proteins, Fish. Elsevier, Amsterdam, Netherland, pp 266-277. 
